\title{
A genetic analysis of human minor histocompatibility antigens demonstrates Mendelian segregation independent of HLA
}

\author{
Geziena M. T. Schreuder'1, Jos Pool1, Els Blokland1, Cécile van Els², Astrid Bakker'1, Jon J. van Rood ${ }^{3}$, \\ Els Goulmy ${ }^{1}$ \\ I Department of Immunohaematology and Blood Bank, University Hospital Leiden, P. O. Box 9600, 2300 RC Leiden, The Netherlands \\ ${ }^{2}$ Department of Immunobiology, RIVM, P. O. Box 1, 3720 BA Bilthoven, The Netherlands \\ ${ }^{3}$ Europdonor Foundation, University Hospital Leiden, P. O. Box 9600, 2300 RC Leiden, The Netherlands
}

Received November 16, 1992

\begin{abstract}
An analysis of the genetic traits of human minor histocompatibility $(\mathrm{mH})$ antigens is, unlike with inbred mice, rather complicated. Moreover, the fact that $\mathrm{mH}$ antigens are recognized in the context of MHC molecules creates an additional complication for reliable segregation analysis. To gain insight into the mode of inheritance of the $\mathrm{mH}$ antigens, we relied upon a series of HLA-A2-restricted cytotoxic T-cell (CTL) clones specific for four $\mathrm{mH}$ antigens. To perform segregation analysis independent of HLA-A2, we transfected HLA-A2-negative cells with the HLA-A2 gene: this results in the cell surface expression of the HLA$\mathrm{A} 2$ gene product and, if present, $\mathrm{mH}$ antigen recognition. The mode of inheritance of the HLA-A2-restricted $\mathrm{mH}$ antigens HA-1, $-2,-4$, and -5 was analyzed in 25 families whose members either naturally expressed HLA-A2 or were experimentally rendered HLA-A2positive. Analysis of distribution of the $\mathrm{mH}$ antigens in the parent population among the mating types, together with their inheritance patterns in the families, demonstrated that the four $\mathrm{mH}$ antigens behaved as Mendelian traits, whereby each can be considered a product of a gene with two alleles, one expressing and one not expressing the detected specificity. We also showed that the loci encoding the HA-1 and HA-2 antigens are not closely linked to HLA (lod scores Z $(0=0.05)<-4.0$ ). Some indication was obtained that the HA-4- and HA5 -encoding loci may be losely linked to HLA. While we are aware of the limited results of this nonetheless comprehensive study, we feel the similarity in immunogenetic traits between human and mouse $\mathrm{mH}$ antigens is at least striking.
\end{abstract}

Correspondence to: E. Goulmy.

\section{Introduction}

An argument that leucocyte groups do exist was found in family studies which showed that leucocyte iso-antigens could be inherited (Van Rood 1962). Since the mode of inheritance of human minor histocompatibility $(\mathrm{mH})$ antigens is sofar unknown, their existence is apparently questionable. The classical definition of $\mathrm{mH}$ loci is, however, also based on their immunogenicity in skin transplant experiments in mice (Snell 1948). The $\mathrm{mH}$ antigenic immunogenicity in humans is reflected by the occurrence of graft-vs-host-disease (GVHD) as well as the rejection of grafts in HLA genotypically identical bone marrow donor/recipient combinations (Thomas et al. 1975; Deeg and Storb 1984).

Until recently, $\mathrm{mH}$ antigen identification was approached solely by in vitro cellular means. In that way, a limited number of $T$ helper (Th) cells and cytotoxic $\mathrm{T}$ lymphocyte (CTL) $\mathrm{mH}$ antigenic determinants was identified (see review Goulmy 1988). Characteristic for $\mathrm{mH}$ antigens is that they are presented by MHC class I and II molecules. By using selective depleted T-cell subsets, we showed that the $\mathrm{mH}$ antigen $\mathrm{Th}$ cell responses are mediated by CD $4+$ ve class II (HLA-DR or $-\mathrm{DP}$ ) restricted $\mathrm{T}$ cells; the $\mathrm{CTL}$ responses have the CD8 phenotype and recognize the $\mathrm{mH}$ antigens in the context of class I (HLA-A or -B) molecules (Goulmy 1988; Van Els et al. 1990).

No information exists on the origin of human $\mathrm{mH}$ antigens. The fact that they are presented by MHC class I (and also MHC class II) molecules favors the idea that they are naturally processed fragments of intracellular proteins which associate with MHC products. Recently, $\mathrm{mH}$ antigen identification was approached by biochemical purification techniques. Rötzschke and colleagues were the first to isolate naturally occurring peptides that represented classical mouse $\mathrm{mH}$ antigens (Rötzschke et al. 1990). Recently, following 
similar immuno and biochemical procedures, we and others have isolated human $\mathrm{mH}$ antıgenic peptides (Sekimata et al 1992, De Bueger et al 1993) Despite the latter advances, the exact amino acid sequence and identity of the protein from which the classical murine or human $\mathrm{mH}$ antigens originate remain to be determined

We recently also obtained information on the polymorphism of the human $\mathrm{mH}$ antigens We used a series of distinct CTL clones specific for five HLA class Irestricted $\mathrm{mH}$ antigens to analyze the phenotype frequencies of $\mathrm{mH}$ antigens $\mathrm{HA}-1,-2,-4$, and -5 in the healthy population These immunogenetic studies revealed that some appeared with high frequencies (HA$295 \%$ ), whereas other $\mathrm{mH}$ antigens occurred with low frequencies (HA-5 7\%, Van Els et al 1992) Using the same CTL clones as genetic probes, we analyzed the mode of inheritance of four HLA-A2- restricted $\mathrm{mH}$ antigens in twenty-five randomly chosen families Segregation of human $\mathrm{mH}$ antigens was proposed earler (Goulmy et al 1982 b, 1988, Zier et al 1983) Here we report that $\mathrm{mH}$ antigens can be considered as independent domanant Mendelian traits Moreover, lod score analyses were carned out on the present family material to analyze the linkage between the $\mathrm{mH}$ antigen loci themselves and between the loci encoding these $\mathrm{mH}$ antigens and HLA

\section{Materials and methods}

mH antigen HA-I -2, 4, and 5 specific CTL clones Five cytotoxic T cell lines (CTLs), designated HA 1 through -5, were isolated from peripheral blood lymphocytes (PBL) obtained from five patients after in vivo sensitization by a bone marrow allograft from their HLA genotypically identical siblings (Goulmy 1988) The CTL lines were suspended at 15 cells $/ \mathrm{ml}$ in a feeder cell mixture and plated at $02 \mathrm{ml} /$ well ( $1 \mathrm{e}, 03 \mathrm{cells} /$ well) of 96 -well round bottom microtiter plates Clones with antihost cytotoxic activity were selected and large scale expansion ( 30 to 60 -fold) of these clones for extensive panel typing $(\mathrm{N}=100$ ) was performed Four distinct clusters of $\mathrm{mH}$ antigen-spectfic clones, restricted by HLA-A2 (HA-1,2, 4, and 5), were identified in this way (Van Els et al 1992)

Cell mediated lympholysis (CML) assay Cell-mediated lympholysis was measured in vitro by using a standard chromium release assay (Goulmy 1982 a)

Class I gene transfection We used electroporation (Potter et al 1984) to introduce cloned HLA genes into the Epstein-Barr Virus (EBV) transformed B-cell lines We transfected the HLA A2 gene cloned in the pHEBO vector (Sugden et al 1985, Shimizu et al 1986) into HLA-A2 negative cells Fluorescence activated cell sorter (FACS) analyses using the class I and HLA A2 specific monoclonal antibodies were carried out and demonstrated the surface expression of the HLA-A2 gene product on all transfected cells Subsequently, the transfected cell lines were subjected to $\mathrm{mH}$ typing (Goulmy et al 1991)

Familes Twenty five families, previously HLA typed for various reasons, were avaulable Four of these were kindly provided by
J Dausset In fourteen families both parents were HLA A2 positive From nune of these famulies lymphocytes from the HLA A2 nega tuve members $(N=14)$ were rendered $A 2$ positive by electropora tion In addition lymphocytes from all the members of five HLA A2 negative families were rendered A2 positive by electroporation Those five families were only tested for HA 1 and HA 2

Test for segregation in families If the genetics of $\mathrm{mH}$ antigens are comparable to blood groups they should be inherited in a simple way (Race and Sanger 1954) They should be controlled by sets of allelic genes that follow the Mendelian laws We tested the hypothe sis that each of the HLA A2 restricted $\mathrm{mH}$ antigens is inherited as an independent dominant Mendelian character

The material presented here enabled us to perform the following analyses

1) Using the parents as a random population to compare their respec tive phenotype (pf) and gene (gf) frequencies, with those previously published (Van Els et al 1992),

2) To test whether Mendelian traits are randomly distributed among the mating types of the parents,

3) To test whether Mendelian trats are inherited by the progeny in a predictive fashion However, as pointed out by Smith (1956), a slight over representation of individuals expressing the dominant trait may influence the $\mathrm{X}^{2}$ unfavorably We followed the method suggested by Smith (1956), which compares the distribution of recessive offspring within and among the families tested, with the expected distribution The $\mathrm{X}^{2}$ was calculated as $\mathrm{X}^{2}=$ (observed - expected $)^{2} /$ variance

Recessive children can be a result of $+x-$ mating if the parental genes were $+-x--$ or from $a+x+$ mating if the parental genes were $+-x+-$

The test can then be divided into two parts 1) matings with at least one recessive child should results in a reasonable number of recessive children in all, 2) The distribution of matıngs resulting in recessive children can be checked against those without any reces sive children

The gf of HA-1 HA 4, and HA 5 were published previously as 044322008348 , and 003564 , respectively, whereas the pf of HA-2 was estımated as $95 \%$ (see Table 1) The $\mathrm{mH}$ antrgen phenotypes are designated HA-1, HA 2, and so on, and the non expressing pheno type ha 1, ha-2, and so on The frequency of the allele encoding the expressed $\mathrm{mH}$ antigen can be called $\mathrm{p}$ and of the nonexpressed allele $q$, where $p+q=1$ The $p f$ and gf are shown in Table 1

When the number of observations is very close to the expected number, $\mathrm{X}^{2}$ values are low and consequently, $\mathrm{p}$ values are high, $1 \mathrm{e}$, $>005$, indicating a good fit to the expectations

Lod score analyses for linkage of each of the $\mathrm{mH}$ antigens with HLA was performed in double backcross families using the formula of Morton (1956)

$\mathrm{Z}(\boldsymbol{\theta})=\log 2^{\mathrm{s} 1}+\log \left[\theta^{\mathrm{s}}\left(1 \theta^{\mathrm{s} r}+\theta^{\mathrm{s} r}(1)^{\mathrm{s}}\right]\right.$,

where $\theta=$ the recombination fraction (theta),

$\mathrm{s}=$ the total number of children,

and $\quad r=$ the number of children having one type

Table 1. Phenotype (pf) and gene (gf) frequencies of the HLA-A2 restricted $\mathrm{mH}$ antıgens (Van Els et al 1992)

\begin{tabular}{llll}
\hline Spec & $\begin{array}{l}\text { Phenotype } \\
\text { frequency }\end{array}$ & $\begin{array}{l}\text { gf } \mathrm{p}= \\
\text { expressing }\end{array}$ & $\begin{array}{l}\text { gf } \mathrm{q}= \\
\text { non expressing }\end{array}$ \\
\hline HA-1 & $69 \%$ & 044 & 056 \\
HA-2 & $95 \%$ & 077 & 023 \\
HA-4 & $17 \%$ & 009 & 091 \\
HA-5 & $8 \%$ & 004 & 096 \\
\hline
\end{tabular}


Table 2. Antigen expression in families

\begin{tabular}{|c|c|c|c|c|c|c|c|c|c|}
\hline \multicolumn{10}{|c|}{ A Expression of HA-1 and HA-2 antigens } \\
\hline \multirow{2}{*}{$\begin{array}{l}\text { Fam } \\
\text { Name }\end{array}$} & \multirow{2}{*}{$\begin{array}{l}\text { No } \\
\text { children }\end{array}$} & \multicolumn{2}{|c|}{ HA-1 } & \multicolumn{2}{|c|}{ Children } & \multicolumn{2}{|c|}{$\mathrm{HA}-2$} & \multicolumn{2}{|c|}{ Children } \\
\hline & & P1 & $\mathrm{P} 2$ & pos & neg & $\mathrm{P} 1 \neq$ & $\mathbf{P} 2 \neq$ & pos & neg \\
\hline Nach & 3 & + & + & 3 & 0 & + & + & 3 & 0 \\
\hline Nus* & 3 & + & + & 3 & 0 & + & + & 3 & 0 \\
\hline Hart & 4 & + & + & 2 & 2 & + & + & 1 & 3 \\
\hline Dirw ${ }^{+}$ & 4 & + & + & 4 & 0 & + & + & 4 & 0 \\
\hline $\mathrm{Pool}^{+}$ & 4 & + & + & 3 & 1 & + & + & 4 & 0 \\
\hline $\mathrm{Otte}^{+}$ & 5 & + & + & 5 & 0 & + & + & 5 & 0 \\
\hline Creg & 6 & + & + & 6 & 0 & + & + & 6 & 0 \\
\hline Hoge & 6 & + & + & 6 & 0 & + & + & 6 & 0 \\
\hline Kop & 8 & + & + & 8 & 0 & + & + & 8 & 0 \\
\hline deRy* & 9 & + & + & 9 & 0 & + & + & 9 & 0 \\
\hline $\mathrm{vdBr}^{+}$ & 10 & + & + & 7 & 3 & + & - & 10 & 0 \\
\hline Wild* & 3 & + & - & 1 & 2 & + & + & 3 & 0 \\
\hline WdV1 & 3 & + & - & 3 & 0 & + & + & 3 & 0 \\
\hline WdV2 & 4 & + & - & 1 & 3 & + & + & 4 & 0 \\
\hline Goek* & 4 & + & - & 3 & 1 & + & + & 4 & 0 \\
\hline $\mathrm{Back}^{+}$ & 5 & + & - & 5 & 0 & + & + & 5 & 0 \\
\hline Dyeu & 5 & + & - & 3 & 2 & + & + & 5 & 0 \\
\hline Viss & 5 & + & - & 4 & 1 & + & + & 5 & 0 \\
\hline Koud* & 5 & + & - & 5 & 0 & + & + & 5 & 0 \\
\hline Gys** & 10 & + & - & 8 & 2 & + & + & 10 & 0 \\
\hline Rooy & 13 & + & - & 13 & 0 & + & + & 5 & 8 \\
\hline Pasc & 4 & - & - & 0 & 4 & + & + & 4 & 0 \\
\hline Capt* & 4 & - & - & 0 & 4 & + & + & 4 & 0 \\
\hline Aang* & 5 & - & - & 0 & 5 & + & + & 5 & 0 \\
\hline Robi* & 7 & - & - & 0 & 7 & + & - & 7 & 0 \\
\hline
\end{tabular}

B Expression of HA-4 and HA-5 antigens

\begin{tabular}{|c|c|c|c|c|c|c|c|c|c|}
\hline \multirow{2}{*}{$\begin{array}{l}\text { Fam } \\
\text { Name }\end{array}$} & \multirow{2}{*}{$\begin{array}{l}\text { No } \\
\text { children }\end{array}$} & \multicolumn{2}{|c|}{$\mathrm{HA}-4$} & \multicolumn{2}{|c|}{ Children } & \multicolumn{2}{|c|}{ HA-5 } & \multicolumn{2}{|c|}{ Children } \\
\hline & & P1 & $\mathrm{P} 2$ & pos & neg & P1 & $\mathrm{P} 2$ & pos & neg \\
\hline Niys* & 3 & + & - & 2 & 1 & - & - & 0 & 3 \\
\hline Nach & 3 & + & - & 3 & 0 & - & - & 0 & 3 \\
\hline Dyeu & 5 & + & - & 3 & 2 & + & - & 2 & 3 \\
\hline Robi* & 7 & + & - & 6 & 0 & - & - & 0 & 6 \\
\hline Kop & 8 & + & - & 3 & 5 & - & - & 0 & 8 \\
\hline Gyjs* & 10 & + & - & 1 & 7 & - & - & 0 & 8 \\
\hline WdV1 & 3 & - & - & 0 & 3 & - & - & 0 & 3 \\
\hline Hart & 4 & - & - & 0 & 4 & + & - & 2 & 2 \\
\hline WdV2 & 4 & - & - & 0 & 4 & + & - & 1 & 3 \\
\hline Koud* & 5 & - & - & 0 & 4 & - & - & 0 & 4 \\
\hline Creg & 0 & - & - & 0 & 6 & - & - & 0 & 6 \\
\hline Hoge & 6 & - & - & 0 & 6 & - & - & 0 & 6 \\
\hline deRy* & 9 & - & - & 0 & 9 & + & - & 2 & 7 \\
\hline Rooy & 13 & - & - & 0 & 13 & - & - & 0 & 13 \\
\hline Pasc & 4 & nt & $\mathrm{nt}$ & nt & nt & - & - & 0 & 4 \\
\hline Viss & 5 & nt & nt & nt & $\mathrm{nt}$ & - & - & 0 & 5 \\
\hline
\end{tabular}

* Farulies with at least two HLA-A2-positive haplotypes, cells from A2-negative family members were rendered A2-positıve by electroporation

+ HLA-A2-negative famulies, rendered $H L A A 2$-posttive by electroporation

₹ Pl, P2 parent 1 , parent 2 
Table 3. Segregation of HA 1

A Number of ha- 1 children in families with at least one ha- 1 child

\begin{tabular}{|c|c|c|c|c|c|c|}
\hline \multirow{2}{*}{$\begin{array}{l}\text { Matıng } \\
\text { type }\end{array}$} & \multirow{2}{*}{$\begin{array}{l}\text { Fam } \\
\text { sile }\end{array}$} & \multirow{2}{*}{$\begin{array}{l}\text { No } \\
\text { fams }\end{array}$} & \multicolumn{4}{|c|}{ No of ha- 1 children } \\
\hline & & & obs & $\exp$ & variance & $\mathrm{X}^{2}$ \\
\hline$+x+$ & $\begin{array}{r}4 \\
10\end{array}$ & $\begin{array}{l}2 \\
1\end{array}$ & $\begin{array}{l}3 \\
3 \\
6\end{array}$ & $\begin{array}{l}2926 \\
2649 \\
5575\end{array}$ & $\begin{array}{l}0840 \\
1592 \\
2432\end{array}$ & $0074(\mathrm{~ns})$ \\
\hline$+x-$ & $\begin{array}{r}3 \\
4 \\
5 \\
10\end{array}$ & $\begin{array}{l}1 \\
2 \\
2 \\
1\end{array}$ & $\begin{array}{r}2 \\
4 \\
3 \\
2 \\
11\end{array}$ & $\begin{array}{r}1714 \\
4266 \\
5162 \\
5005 \\
16147\end{array}$ & $\begin{array}{l}0490 \\
1564 \\
2164 \\
2478 \\
6696\end{array}$ & $3956(p=0047)$ \\
\hline
\end{tabular}

B Number of families with at least one ha- 1 child vs all families

\begin{tabular}{|c|c|c|c|c|c|c|}
\hline \multirow{2}{*}{$\begin{array}{l}\text { Matıng } \\
\text { type }\end{array}$} & \multirow{2}{*}{$\begin{array}{l}\text { Fam } \\
\text { size }\end{array}$} & \multirow{2}{*}{$\begin{array}{l}\text { No } \\
\text { fams }\end{array}$} & \multicolumn{4}{|c|}{ No of fams with ha-1 children } \\
\hline & & & obs & $\exp$ & variance & $\mathrm{X}^{2}$ \\
\hline$+x+$ & $\begin{array}{r}3 \\
4 \\
5 \\
6 \\
8 \\
9 \\
10\end{array}$ & $\begin{array}{r}2 \\
3 \\
1 \\
2 \\
1 \\
1 \\
\frac{1}{11}\end{array}$ & $\begin{array}{l}0 \\
2 \\
0 \\
0 \\
0 \\
0 \\
-1 \\
3\end{array}$ & $\begin{array}{l}0595 \\
1058 \\
0393 \\
0847 \\
0464 \\
0477 \\
0486 \\
4320\end{array}$ & $\begin{array}{l}0418 \\
0 \quad 685 \\
0239 \\
0489 \\
0249 \\
0249 \\
0250 \\
2579\end{array}$ & 0675 (ns) \\
\hline$+x-$ & $\begin{array}{r}3 \\
4 \\
5 \\
10 \\
13\end{array}$ & $\begin{array}{r}2 \\
2 \\
4 \\
1 \\
1 \\
10\end{array}$ & $\begin{array}{l}1 \\
2 \\
2 \\
1 \\
0 \\
6\end{array}$ & $\begin{array}{l}1256 \\
1347 \\
2782 \\
0718 \\
0717 \\
6820\end{array}$ & $\begin{array}{l}0.467 \\
0880 \\
0849 \\
0203 \\
\frac{0.202}{2601}\end{array}$ & 0.258 \\
\hline \multicolumn{3}{|c|}{ Total $X^{2}(a+b)$} & & & $4 \mathrm{df}$ & 4963 (n s) \\
\hline
\end{tabular}

\section{Results and discussion}

$m H$ antigen HA-1. In Table 2A the distribution of HA-1 in the 25 families is shown.

1) The HA-1 phenotype distribution among the 50 parents was compared with the expected distribution as shown below:

$$
\begin{aligned}
& \text { Phen Genotype N exp Nobs } \\
& \text { HA-1 }++=p^{2}=044^{2}=0194 \\
& +-=2 \mathrm{pq}=2 \times 0.44 \times 056=\underline{0.493} \\
& \begin{array}{llllll}
\text { ha-1 }--=q^{2}=056^{2} & =0687 & 343 & 32 & 015 \\
0314 & \frac{157}{500} & \frac{18}{50} & \frac{034}{049}=X^{2}
\end{array}
\end{aligned}
$$

We can conclude that the HA-1 distribution in the parent population is not significantly different from the expected values $\left(X^{2}=0.49, p>0.05\right)$.

2) The distribution of mating types over the families was compared with the expected distribution, which can be calculated as follows:

$$
\begin{aligned}
& \text { Matıng types exp obs } \\
& \mathrm{HA}-1 \times \mathrm{HA}^{-1}=0686^{2}=0470 \quad 1175 \quad 110.048 \\
& \text { HA }-1 \times \text { ha- } 1=2 \times 686 \times 313=0432 \quad 1080 \quad 100059 \\
& \text { ha- } 1 \times \text { ha-1 }=0313^{2}=\underline{0097} \quad 245 \quad 4 \quad 0980 \\
& \frac{000}{1000} \quad \frac{4}{25} \quad \frac{0980}{1087}=X^{2}
\end{aligned}
$$

We can conclude that the distribution of the mating types of the 25 families is according to expectation $\left(\mathrm{X}^{2}=1.087, \mathrm{p}>0.05\right)$.

3) Using the methods described by Smith (1956) we tested first the distribution of recessive children from $+x+$ matings. As can be seen in Table 2A, 11 families had this mating type, three of which had ha-1 offspring. The expected number of ha- 1 children and its variance were calculated for each family size observed. The combined results allowed for comparison with the observed number of ha-1 children and was according to expectation $\left(\mathrm{X}^{2}=0.0742\right.$, Table $\left.3 \mathrm{~A}\right)$. If HA-1 is a Mendelian trait the number of families that have at least one ha-1 child can be estimated using the HA-1 gf, $q=.44$. Although the number of families with ha-1 
Table 4. HA-2 Phenotype distribution

\begin{tabular}{llll}
\hline A In parent population & & & \\
\hline & obs & $\exp$ & $\mathrm{X}^{2}$ \\
\hline HA-2 & 48 & 4736 & 004 \\
ha-2 & $\underline{2}$ & $\underline{264}$ & $\underline{001}$ \\
& 50 & 5000 & 005 (n s) \\
\hline
\end{tabular}

B Among matung types

\begin{tabular}{lrrl}
\hline Matıng & obs & exp & $\mathrm{X}^{2}$ \\
\hline$+x+$ & 23 & 2256 & 0008 \\
$+x-$ & 2 & 237 & 0057 \\
$-x-$ & 0 & 006 & 0060 \\
& 25 & 2499 & 0125 (n s) \\
\hline
\end{tabular}

C Segregation of HA-2 comparing

1) Number of ha- 2 children in families with at least one ha- 2 child (methods analogous to those given in Table 3)

\begin{tabular}{lllll}
\hline $\begin{array}{l}\text { Mating } \\
\text { type }\end{array}$ & \multicolumn{2}{c}{ ha-2 children } & & \\
\cline { 2 - 5 } & obs & $\exp$ & vanance & $X^{2}$ \\
\hline$+x+$ & 11 & 3520 & 1435 & 3898 \\
$+x-$ & 0 & - & - & -
\end{tabular}

2) Number of families with at least one ha-2 child vs all famılies

\begin{tabular}{lcccc}
\hline $\begin{array}{l}\text { Matıng } \\
\text { type }\end{array}$ & \multicolumn{2}{l}{ Fam with ha-2 child } & & \\
\cline { 2 - 5 } & obs & $\exp$ & variance & $X^{2}$ \\
\hline$+\times+$ & 2 & 2387 & 2138 & 007 \\
$+\times-$ & 0 & 0745 & 0466 & 119 \\
Total X & & & $3 \mathrm{~d} \mathrm{f}$ & 4024 \\
\hline
\end{tabular}

children was small, it was according to expectation $\left(X^{2}=0.675\right.$, Table 3B). Ten families showed the $+X-$ mating type. The number of ha-1 children in these families was slightly different from the expected number $\left(X^{2}=3.956, p=0.047\right)$, but the fact that they were observed in six of ten families was according to expectation $\left(X^{2}=0.258\right.$, Table 3). The total $X^{2}(a+b)$ indicates that the HA-1 segregation agrees satısfactorily with our hypothesis of a genetic trait that follows Mendelian laws (Table 3). The same methods as described above were used to analyze the segregation of HA-2, HA-4, and HA-5.

$m H$ antigen HA-2. As can be seen in Table 2A, only two parents had the ha-2 phenotype. However, this was according to our expectations as shown in Table $4 \mathrm{~A}$. The observation of only two families with the $+x-$ mating type was not significantly different from that expected (Table 4B).

The number of ha-2 children detected in the two $+x+$ families was much larger than expected
$\left(\mathrm{X}^{2}=38.98\right)$, but this may be due to having had so few families. However, the fact that only two such families were found among all the families was according to expectation (see Table $4 \mathrm{c}$ ). The very high frequency of HA-2 greatly restricts the number of analyzable families.

$m H$ antigen HA-4. Six of 28 parents were HA-4 positive, and they all belonged to $+x-$ matings (Table $2 B$ ). Both observations were according to expectation (Table 5A, B). Since the $+x+$ mating type was not represented, we could only test the number of recessive children in the $+x-$ matings. Their number, as well as the number of families in which they were observed, fulfilled the criteria for Mendelian segregation (Table 5C).

$m H$ antigen HA-5. The HA-5 specificity is even less frequent than of HA-4 (gf.p = 0.04). The chance of finding HA-5-positive individuals is low and that of $+x+$ matıngs is extremely low. However, the four 
G M T Schreuder et al Segregation of human minor histocompatıbility antıgens

Table 5. HA-4 phenotype distribution

\begin{tabular}{lccc}
\hline A In parent population & & & \\
\hline & obs & exp & $X^{2}$ \\
\hline HA-4 & 6 & 481 & 029 \\
ha 4 & 22 & 2319 & 006 \\
& 28 & 2800 & 035 \\
\hline
\end{tabular}

B Among mating types

\begin{tabular}{lccc}
\hline Mating & obs & exp & $\mathrm{X}^{2}$ \\
\hline$+\times+$ & 0 & 042 & 042 \\
$+\times-$ & 6 & 392 & 113 \\
$-\times-$ & $\underline{866}$ & $\underline{0.27}$ \\
\hline
\end{tabular}

C Segregation of HA-4 comparıng

1) Number of ha- 4 children in families with at least one ha- 4 child

\begin{tabular}{lllll}
\hline $\begin{array}{l}\text { Mating } \\
\text { type }\end{array}$ & ha-4 children & & & $X^{2}$ \\
\cline { 2 - 5 } & obs & $\exp$ & varrance & 1308 \\
$+x+$ & 0 & - & - & 5462
\end{tabular}

2) Number of familes with at least one ha-4 child vs all families

\begin{tabular}{|c|c|c|c|c|}
\hline \multirow{2}{*}{$\begin{array}{l}\text { Matıng } \\
\text { type }\end{array}$} & \multicolumn{4}{|c|}{ Fam with ha- 4 child } \\
\hline & obs & $\exp$ & varıance & $\mathrm{X}^{2}$ \\
\hline$+x+$ & 0 & - & - & \\
\hline$+x+$ & 4 & 516 & 0645 & 2.086 \\
\hline \multicolumn{3}{|c|}{ Total X $X^{2}(\mathrm{c} 1+2)$} & $2 \mathrm{~d} \mathrm{f}$ & $3394(\mathrm{n} \mathrm{s})$ \\
\hline
\end{tabular}

observed HA-5-positive parents giving rise to four $+x-$ matings all agreed with the expected values. Thus, HA-5 behaves as a Mendelian trait (Table 6).

$m H$ antigens and HLA. We have shown that each of the four $\mathrm{mH}$ antigens can be considered a product of a locus with two alleles. Are these loci 1) independent of HLA and 2) independent of each other?

For each of the $\mathrm{mH}$ antigens a number of double back-cross families were analyzed for linkage with HLA. In families with the $+x+$ HA mating types, only the HA-negative children were counted. The results are shown in Table 7. HA-1 and HA-2 did not appear to be closely linked to HLA, since their lod scores are below -2.0 at recombination fractions $0=0.05$, and 0.10 . HA4 showed a positive lod score which was highest at $0=0.1$. However, this score was not sufficiently high to ensure linkage between both loci. Weak but insignificant positive linkage between HLA and HA-5 was found. In one family an HLA-A:B recombinant hap- pened to be informative for HA-5. If HA-5 is linked to HLA its location is most likely centromeric to HLA-A.

Linkage studies between the $\mathrm{mH}$ antigens themselves revealed hardly any informative double backcross families. This is due to the very high frequency of HA-2 and the very low frequencies of HA-4 and HA-5. Two families were informative for HA-1: HA-5 linkage and one family for HA-2: HA-5, both resulting in weak negative lodscores (Table 7). There were no informative families for the other combinations.

Although these data are really very few and insignificant, they at least do not contradict the above observation that $H A-1$ and $H A-2$ loci are definitely not linked to HLA, whereas HA-5 may be linked. The linkage between HA-1 and HA-2 could not be established with only one informative family.

To summarize, all four HLA-A2-restricted $\mathrm{mH}$ antigens behaved as Mendelian traits in tests for their phenotype distribution and segregation. Each can be considered a product of a gene with two alleles, one 
Table 6. HA 5 phenotype distribution

\begin{tabular}{lccc}
\hline A In parent population & & & \\
\hline & obs & exp & $X^{2}$ \\
\hline HA 5 & 4 & 251 & 088 \\
ha 5 & $\frac{28}{32}$ & $\frac{2949}{3200}$ & 097 \\
\hline B Among mating types & & & $X^{2}$ \\
\hline Matıng & obs & exp & 010 \\
\hline$+x+$ & 0 & 01 & 126 \\
$+x-$ & 4 & 23 & 019 \\
$-x-$ & 12 & 136 & 155 \\
\hline
\end{tabular}

C Segregation of HA 5 comparing

1) Number of ha 5 children in famulies with at least one ha 5 child

\begin{tabular}{lcccc}
\hline $\begin{array}{l}\text { Matıng } \\
\text { type }\end{array}$ & ha 5 chldren & & vanance & $X^{2}$ \\
\cline { 2 - 4 } & obs & exp & - & \\
$+x+$ & 0 & - & 4861 & 273
\end{tabular}

2) Number of families with at least one ha 5 child vs all families

\begin{tabular}{|c|c|c|c|c|}
\hline \multirow{2}{*}{$\begin{array}{l}\text { Matıng } \\
\text { type }\end{array}$} & \multicolumn{4}{|c|}{ Fam with ha- 6 child } \\
\hline & obs & $\exp$ & vanance & $\mathrm{X}^{2}$ \\
\hline$+x+$ & 0 & - & - & \\
\hline$+x-$ & 4 & 3765 & 0213 & $\underline{0.26}$ \\
\hline \multicolumn{3}{|c|}{ Total $X^{2}(\mathrm{c} 1+2)$} & $2 \mathrm{df}$ & 299 (ns) \\
\hline
\end{tabular}

Table 7. Lod scores for linkage between HLA and HA 1, HA-2, HA-4, and HA 5

\begin{tabular}{|c|c|c|c|c|}
\hline & $\theta=005$ & 010 & 020 & 030 \\
\hline \multicolumn{5}{|l|}{ HLA HA $I$ (counts) } \\
\hline 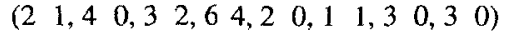 & -4815 & -2357 & -0519 & 0010 \\
\hline HLA HA $2\left(\begin{array}{lllll}3 & 0,1 & 2,5 & 3,5 & 3\end{array}\right)$ & -4000 & -2211 & -0772 & -0232 \\
\hline$H L A H A-4(4 \quad 1,4 \quad 0,0 \quad 3,4 \quad 2,80)$ & 1905 & 2275 & 2037 & 1344 \\
\hline HLA A HA $5\left(\begin{array}{lllll}1 & 4,0 & 4,0 & 4,6 & 3\end{array}\right)$ & -0187 & 0597 & 1101 & 0207 \\
\hline HLA BDR HA $5\left(\begin{array}{l}1 \\
4,0\end{array}\right.$ & 1181 & 1549 & 1490 & 0975 \\
\hline HA 1 HA $5(4$ 1, 11$)$ & -0907 & -0466 & -0070 & 0019 \\
\hline$H A I H A 2(20)$ & 0258 & 0215 & 0134 & 0064 \\
\hline HA 2 HA $5(21)$ & -0721 & -0444 & -0194 & -0076 \\
\hline
\end{tabular}

expressing and one not expressing the detected speciincity Due to the high frequency of HA-2 ( $\mathrm{pf}=95 \%$, gf $=077$ ), only two families were detected with HA-2negative children The distribution of negative children in these two familes was not according to Mendelian segregation, which might be due to the small number of observations But all other tests were in favor of the hypothesis that HA-2 is also encoded by an independent gene

We concluded that the loci encoding HA-1 and HA2 are not linked to the $H L A$ region Our family data dit not provide sufficient information concerning linkage 
between the other mH-encoding locs and HLA or between the $\mathrm{mH}$ loci themselves

The mode of inheritance of the respective HA antigens has considerable implications for bone marrow transplantation Since the HA antigens are not tightly linked to HLA and also probably not to each other, the selection of HLA-identical family members does not implicate matchıng for the $\mathrm{mH}$ antigens However, among family members the chance of being HLA and HA-1denticdl is higher than among HLA-1dentical unrelated individuals (Martın 1991) It is clear that the differences in frequency distribution of the $\mathrm{mH}$ antigens is also important The chance of matching two unrelated HLA-identical individuals for $\mathrm{mH}$ antigens with very high (HA-2) or very low frequencies (HA-5) will be higher than for those minors with an equal allelic distribution, such as HA-1 However, our observatıons only concern HLA-A2-restricted $\mathrm{mH}$ antigens, and many more as yet unknown antigens may play a role in GVHD Although multıple $\mathrm{mH}$ antigen disparıties between HLA-matched individuals may exist, T-cell responses against immunodominant $\mathrm{mH}$ antigens will prevail, as was clearly demonstrated earlier in mouse models (Wettstein and Balley 1982) and more recently supposed by our own studies (Van Els et al 1992)

Our contribution concerning the mode of inheritance of minor histocompatibility antigens and their distribution in the population may help to elucidate further causes of GVHD in the future

Acknowledgments We would like to thank Professor J Dausset for making avallable to us EBV-transformed cell lines from four HLA A2-positive families We are grateful to Dr L Cavalli-Sforza, Dr J Mountain, Dr C Falk, and Dr J D'Amaro for helpful discussion and valuable advice, and to Ms N Warmerdam and Mrs I Cunel for editing the manuscript This work was supported in part by grarts from the Dutch Foundation for Medical and Health Research (NWO) and Radiopathology and Radiation Protection (IRS)

\section{References}

De Bueger, M, Verreck, F, Blokland, E, Drufhout, J W, Amons, $R$, Koning, F, and Goulmy, E Isolation of an HLA A2 1 extracted human minor histocompatibility peptıde Eur J Immunol $3614-618,1993$

Deeg, $\mathrm{H} \mathrm{J}$ and Storb, R Graft-versus-host disease pathophysiological and clinical aspects Annu Rev Med $3511-24,1984$

Goulmy, E HLA-A, -B restriction of cytoxic T cells in S Ferrone and B G Solheim (eds) HLA Typing Methodology and Clint cal Aspects, vol 2, pp 105-122, CRC press, New York, 1982 a

Goulmy, E Minor Histocompatibility antıgens in man and their role in transplantation In J Morris and N L Tiney (eds) Trans plantation Rev vol 2 pp 29-53, W B Saunders, Harcourt Brace Jovanovich Philadelphid 1988

Goulmy E Gratama J W Blokland E Zwaan F E and Van Rood J J Recognition of an - as yet unknown - minor trans plantation antigen by post-transplant lymphocytes from an A M L patient Exp Hematol 10 (Suppl 10) 127-129 1982 b

Goulmy E, Pool J Blokland E and Geraghty D Transfected human class I gene product adequately assembles minor $\mathrm{H} 1 \mathrm{~s}$ tocompatibility antigen Immunogenetics 34 270-272 1991

Martin P J Increased disparity for minor Histocompatibility an tigens as a potentral cause of increased GvHD risk in marrow transplantation from unrelated donors compared with related donors Bone Marrow Transplant 8 271-273 1991

Morton, $N$ E Sequential tests for the detection of linkage $A m$ J Hum Genet $7277-3181956$

Potter, $H$ Werr L, and Leder P Enhancer dependent expression of human $\mathrm{k}$ immunoglobulin genes introduced into mouse pre $\mathrm{B}$ lymphocytes by electroporation Proc Natl Acad Scl USA 81 $7161-7165,1984$

Race R R and Sanger, R Blood Groups in Man 2nd edn Oxford, Blackwell, 1954

Rotzshke, O, Falk K, Wallny, H J, Faath, S and Rammensee H -G Characterization of naturally occurring minor Histocom patibility peptides including H 4 and H Y Science 249 $283-287,1990$

Sekımata, M , Griem, P , Egawa, K, Rammensee H -G , and Takıgu $\mathrm{ch}, \mathrm{M}$ Isolation of human minor Histocompatibility peptides Int Immunol 4 301 - 304, 1992

Shımızu, Y, Koller, B , Geraghty, D , Orr, H , Shaw, S , Kavathas, $P$, and De Mars, R Transfer of cloned human class I major histocompatibility complex genes into HLA mutant lympho blastord cells Mol Cell Biol 6 1074-1987, 1986

Smith, C A B A test for segregation ratıos in family data Ann Hum Genet $20 \quad 257-265,1956$

Snell, G D Methods for the study of histocompatibility genes $J$ Genet $4987-103,1948$

Sugden, B , Marsh, K, and Yates, J A vector that replicates as a plasmid and can be efficiently selected in B-lymphoblasts transformed by Epstein Barr virus Cell Biol 5 410-413, 1985

Thomas, E D, Storb, R, Clift, R A, Fefer, A, Johnson, F L, Neiman, P E, Lerner, K G, Glucksburg, $H$, and Buckner, C D Bone marrow transplantation New Engl J Med 292 $832-902,1975$

Van Els, C, D'Amaro, J , Pool, J , Blokland, E , Bakker, A, Van den Elsen, P J, Van Rood, J J , and Goulmy, E Immunogenetics of human minor histocompatibility antigens their polymorphism and immunodominance Immunogenetics 35 161-165, 1992

Van Els, C A C M, Zantvoort, E, Jacobs, N, Bakker, A, van Rood, J J and Goulmy, E Graft versus-host disease associated $T$ helper cell responses specific for minor Histocompatibility antigens are mainly restricted by HLA-DR Bone Marrow Transplant 5 365-372, 1990

Van Rood, J J Leucocyte grouping A Method and tts Applicatıon, p 2, Thesis, University of Leiden, Leiden, 1962

Wettstein, P J and Barley, D W Immunodominance in the immune response to 'multiple' histocompatibility antigens Immuno genetics 16 47-58, 1982

Zier, K S , Elkins, W L, Pierson, G R, and Leo, M M The use of cytotoxic $\mathrm{T}$ cell lines to detect the segregation of a human minor alloantigen within familes Hum Immunol 7 117-129, 1983 